\title{
PROJETO DE LEI 4.741/2001: UMA TUTELA JURÍDICA AO MEIO AMBIENTE DE TRABALHO PSICOLOGICAMENTE EQUILIBRADO.
}

\author{
Ângela Diniz Linhares Vieira*
}

\section{RESUMO.}

O texto propõe a possibilidade de proteção ao trabalhador contra a violência perversa provocada pelo assédio moral através de um levantamento, leitura e análise dos vários Projetos de Lei que tramitam no Senado Federal e Câmara dos Deputados, já que não há nenhuma Lei no ordenamento jurídico de âmbito federal aprovado e em vigor sobre o assunto. Em semelhante perspectiva, tem-se a abordagem do Projeto de Lei 4.742 de 2001, apontado como uma possível forma de controle social desta violência perversa.

PALAVRAS-CHAVES. Meio Ambiente de Trabalho. Assédio Moral. Projetos de Lei.

BILL 4,741/2001: a LEGAL GUARDIANSHIP to PSYCHOLOGICALLY BALANCED WORK ENVIRONMENT.

\begin{abstract}
The text proposes the possibility of worker protection against vicious violence caused by bullying through a survey, analysis of several bills that are handled in the Federal Senate and Chamber of Deputies, since there is no law in the legal system of federal approved and in force on the subject. In such perspective, the approach of the Bill of 20014,742 , touted as a possible form of social control this vicious violence.
\end{abstract}

KEYWORDS . Mobbing. Environment of the workplace. Bills.

* Graduada em DIREITO pela UNIVERSIDADE FEDERAL DE GOIÁS (2008); Mestra em DIREITO AGROAMBIENTAL pela UNIVERSIDADE FEDERAL DE MATO GROSSO (2013); Estágio docência em Direito do Trabalho I (2013); Bolsista do Capes (2013 e 2014); Procuradora do Município de Barra do Garças (2015 e 2016); Professora da Faculdade de Ciências Jurídicas e Sociais Aplicadas do Araguaia (2014-2018); Pesquisadora da linha de pesquisa "Direitos Humanos e Cidadania", da Faculdade de Ciências Jurídicas e Sociais Aplicadas do Araguaia (2017).Professora convidada do Curso de Pós-Graduação em Direito Civil e Processual Civil da Faculdade FASIPE onde ministrou a disciplina Cumprimento de Sentença. Atualmente é professora do Instituto Cuiabá de Ensino e Cultura(ICEC) e doutoranda em Ciências Sociais pela Universidade do Vale do Rio Sinos. E-mail: adinizlinhares@yahoo.com.br 


\section{INTRODUÇÃO.}

O presente estudo analisa o assédio moral quando ele se tornou objeto de proteção, partindo da premissa de que a violação à saúde psíquica cometida por este, significa uma afronta aos direitos fundamentais do trabalhador.

Trata-se de matéria de relevo jurídico indiscutível e eminente, atentando-se não apenas para seus elementos configuradores, como também para o tratamento que lhe é conferido pela doutrina e jurisprudência brasileira.

O objeto deste trabalho circunscreve-se ao regramento atual do meio ambiente do trabalho e de que forma a proteção à saúde mental do trabalhador se dará. Para tanto, procurarse-á as propostas de projeto de lei, uma vez que não há legislação federal sobre o assunto.

O tema em epígrafe tem sido desenvolvido recentemente por juristas brasileiros e estrangeiros, revestindo de inquestionável atualidade, de interesse doutrinário e prático marcantes.

A pesquisa será de natureza bibliográfica, pois se realizará a partir de registro disponível, decorrente de pesquisas anteriores, em documento impressos, como livros, artigos,teses, dentre outros.

Para a investigação serão usados os seguintes recursos técnico-metodológicos: fichamentos, resumos e relatórios a partir de leitura sistemática e atenta do referencial bibliográfico.

\section{INEXISTÊNCIA DE TUTELA JURÍDICA DE ÂMBITO FEDERAL À INDENIDADE PSÍQUICA DO TRABALHADOR.}

O rol de direitos fundamentais, que são aqueles direitos sem os quais a vida humana não pode se desenvolver plenamente, prevê tanto o meio ambiente quanto o trabalho, assim, tais direitos não poderm ser suprimidos ou restringidos.

Segundo Talden Queiroz Farias (2015, p.450):

A classificação de um direito como direito humano fundamental no texto constitucional implica a obrigatoriedade da participação do Estado e da coletividade em torna-lo efetivo, por meio de ações comissivas ou omissivas. Prova disso é que o $\$ 1^{o}$ do art. $5^{\circ}$ da Constituição Ffederal 
determina que "As normas definidoras dos direitos e garantias fundamentais têm aplicação imediata".

Assim como os direitos humanos, os direitos fundamentais são classificados de acordo com três dimensões que geralmente lhe classificam conforme a evolução histórica. Os direitos individuais ou civis e políticos caracterizam os direitos fundamentais de primeira dimensão.

O direitos fundamentais de segunda dimensão, conforme Talden Queiroz, são o direito à educação, à moradia, à alimentação, à segurança social, à cultura, ao amparo à doença, ao amparo à velhice e, principalmente ao trabalho.

Enquanto, nos direitos fundamentais de terceira dimensão tem-se os transindividuais, cuja titularidade não pertence a um indivíduo ou a um grupo determinado, e sim a toda a coletividade indistintivamente. Dentre eles, destacam-se, segundo Talden Queiroz (2015,p. 450) o direito ao consumo, à autodeterminação dos povos, à paz, ao desenvolvimento e, principalmente, ao meio ambiente ecologicamente equilibrado.

Com a utilização do termo dimensões subentende-se que a interdependência e a complementaridade são características dos direitos fundamentais da pessoa humana, ou seja, a aplicação e a efetivação de um, certamente, provocará consequências nos outros.

Por isso, as condições de trabalho estão ligadas à saúde e à qualidade de vida do trabalhador, que passa grande parte da vida no meio ambiente do trabalho, desta forma os direitos trabalhistas são assim respaldados na Constituição Federal (1988):

Art. $7^{\circ}$ São direitos dos trabalhadores urbanos e rurais, além de outros que visem à melhoria de sua condição social:

$[\ldots]$

XXII - redução dos riscos inerentes ao trabalho, por meio de normas de saúde, higiene e segurança;

XXIII - adicional de remuneração para as atividades penosas, insalubres ou perigosas, na forma da lei;

$[\ldots]$

Quanto ao meio ambiente sua previsão encontra-se no art. 225 da Constituição da República Federativa do Brasil (1988), onde,

Todos têm direito ao meio ambiente ecologicamente equilibrado, bem de uso comum do povo e essencial à sadia qualidade de vida, impondose ao Poder Público e à coletividade o dever de defendê-lo e preservá-lo para as presentes e futuras gerações.

De fato, os direitos trabalhistas e o direito ao meio ambiente ecologicamente equilibrado são tutelados pela Constituição Federal, contudo, há uma ligação entre eles, conforme explica Talden Queiroz (2015, p. 462), as mesmas condutas que lesam os trabalhadores também podem causar danos ambientais.(2015, p. 451) Por isso, a necessidade 
de atuação integrada do Poder Público nessa duas áreas que a Constituição Federal (1988) consagrou:

Art. 200 Ao sistema único de saúde compete, além de outras atribuições, nos termos da lei:

$[\ldots]$ o do trabalho.

VIII- colaborar na proteção do meio ambiente, nele compreendendo

A dignidade da pessoa humana, valor constitucional supremo que fundamenta todos os direitos e garantias fundamentais, previsto no inciso III do art. $1^{\circ}$ da Constituição Federal, abarca tanto o meio ambiente quanto o trabalho como valores que dela se originam.

A tutela do meio ambiente trabalhista pela Constituição Federal teve como finalidade proteger a saúde física e mental de todo trabalhador. Segundo Talden Queiroz (2015, p. 464):

O cerne desse conceito está baseado na promoção da salubridade e da incolumidade do trabalhador, independemente de atividade, do lugar ou da pessoa que a exerça, e é por isso que vendedores autônomos e os trabalhadores avulsos também devem ser protegidos.

Dada a amplitude da proteção ao meio ambiente do trabalho, que não se restringe às relações de caráter empregatício, resta analisar o que o Poder Público tem feito para assegurálo equilibrado, já que a Constituição Federal (1988) no inciso V, do $§ 1^{\circ}$ do art. 225, assim o incumbe.

A partir dessa incumbência do Poder Público, primeiro item analisará se há, no âmbito federal, alguma legislação protegendo o trabalhador do Assédio Moral.

Os próximos itens têm por objetivo fazer um levantamento de todos os projetos de lei que protegem a indenidade psíquica do trabalhador diante do assédio moral, tendo em vista a inexistência de regulamentação com vigência e eficácia de âmbito federal, sobre o assunto.

\subsection{A INEXISTÊNCIA DE REGULAMENTAÇÃO DE ÂMBITO FEDERAL SOBRE O ASSÉDIO MORAL.}

Ao contrário do common law, sistema jurídico que basea-se nas decisões do tribunais, onde o direito é criado ou aperfeiçoado pelos juízes e não necessita de positivação das leis, o ordenamento jurídico brasileiro, adotou o civil law, desta forma os fatos sociais relevantes para serem tutelados juridiciamente precisam ser positivados. 
No entanto, a sociedade evolui rapidamente e o direito não consegue acompanhá-la, podendo acontecer que um fato danoso para a sociedade não encontre lei que o discipline.

$\mathrm{O}$ assédio moral configura esse fato danoso sem previsão específica em lei de âmbito federal. Embora existam projetos de lei a respeito do tema que, se fossem aprovados, o trabalhador poderia ter sua incolumidade psíquica bem resguardada.

Referidos projetos são: Projeto de Lei n. 4.742 de 2001; Projeto de Lei n. 2.369 de 2003; Projeto de Lei do Senado n. 121 de 2009; Projeto de Lei n. 7.202 de 2010; e Projeto de Lei n. 3.760 de 2013.

\subsubsection{O assédio moral como ilícito civil: projeto de lei n. 2.369 de 2003.}

O Projeto de Lei n. 2.369 de 2003, de autoria do Deputado Federal Mauro Guimarães Passos, objetiva responsabilizar financeiramente o agressor.

$\mathrm{O}$ art. $1^{\circ}$ deste projeto de lei, é bem enfático ao dispor que é proibido o assédio moral nas relações de trabalho, que, segundo o Art. $2^{\circ}$ consiste:

[...] no constrangimento do trabalhador por seus superiores hierárquicos ou colegas, através de atos repetitivos, tendo como objetivo, deliberado ou não, ou como efeito, a degradação das relações de trabalho e que:

I- atente contra sua dignidade ou seus direitos, ou

II- afete sua higidez física ou mental, ou

III - comprometa a sua carreira profissional (BRASIL, 2003)

Portanto, se o fato ílicito, assédio moral, for cometido, será devida indenização pelo empregador ao empregado sujeito a assédio moral, ressalvado o direito de regresso, redação do art. $3^{\circ}$, caput, dispondo o parágrafo primeiro sobre o valor da indenização:

$\S 1^{\circ} \mathrm{A}$ indenização por assédio moral tem valor mínimo equivalente a 10 (dez) vezes a remuneração do empregado, sendo calculada em dobro em caso de reincidência. (BRASIL, 2003)

Ao Projeto de Lei 2.369 de 2003 foram apensados o dois projetos: o Projeto de Lei 6.625 de 2009 e o Projeto de Lei 6.757 de 2010.

O Projeto n. 6.757 de 2010, de autoria do Senador Inácio Arruda, do PCdo B/CE, altera dispositivos da Consolidação das Leis do Trabalho (CLT), aprovada pelo Decreto-Lei N. 5.452, de $1^{\circ}$ de maio de 1943, para dispor sobre a coação moral, cuja diposição assim ficaria:

Art. $1^{\circ}$ A Consolidação das Leis do Trabalho (CLT), aprovada pelo Decreto-Lei n. 5.454 de $1^{\circ}$ de maio de 1943, passa a vigorar com as seguintes alterações:

"Art. 
h) praticar o empregador ou seus prepostos, contra ele, coação moral, por meio de atos ou expressões que tenham por objetivo ou efeito atingir a dignidade elou criar condições de trabalho humilhantes ou degradantes, abusando da autoridade que lhes conferem suas funções.

$\S 3^{\circ}$ Nas Hipóteses das alíneas 'd', 'g' e ' $h$ ', poderá o empregado pleitear a rescisão de seu contrato e o pagamento das respectivas indenizações, permanecendo ou não no serviço até decisão final do processo.

Art. 484-A Se a rescisão do contrato de trabalho foi motivada pela prática de coação moral do empregador ou de seus prepostos contra o trabalhador, o juiz aumentará, pelo dobro, a indenização devida em caso de culpa exclusiva do empregador.(BRASIL,2010)

Se o empregado sofrer assédio moral, de acordo com o Projeto de Lei n. 6.757 de 2010, poderia reclamar a rescisão indireta do contrato de trabalho, com direito de receber indenização aumentada pelo dobro quando houver culpa exclusiva do empregador.

É de salutar importância o disposto no Projeto de Lei n. 6.757 de 2010, mas o Projeto de Lei n. 6.625 de 2009, elaborado por Aldo Rebelo, do PCdoB/SP, que elucida, minuciosamente, o que seria o assédio moral.

Atenta-se, num primeiro plano, para o que o Projeto de Lei n. 6.757 de 2010, considera como assediador e assediado:

Art. $2^{\circ}$. Para efeito desta lei, considera-se:

I- assediador: aquele que pratica atos de assédio moral, seja como empregador ou preposto deste, ou qualquer funcionário que pratique assédio moral em relação ao colega de trabalho, ainda que superior hierárquico.

II - assediado: aquele que sofre assédio moral de qualquer colega de trabalho ou empregador ou seu preposto.(BRASIL, 2009)

Há, também, as ações que caracterizam o assédio moral, tais como: opção sexual;

a) tratar de forma preconceituosa condições de gênero, etnia e

b) sonegar informações de interesse comum, de forma insistente;

c) obstruir o exercício profissional, por intermédio da retirada e sonegação imotivada de materiais e equipamentos necessários ao desenvolvimento das tarefas;

d) divulgar informações maliciosas a respeito do empregado no ambiente de trabalho;

e) apropriar-se do crédito de ideias, propostas, projetos ou de qualquer trabalho de subordinado ou de colega de trabalho;

f) valer-se de ordens e orientações confusas ou contraditórias com a finalidade de induzir empregado a erro;

g) explorar fragilidades físicas e psíquicas do empregado em qualquer momento;

h) desrespeitar limites decorrentes de condições de deficiência física e mental impondo ao trabalhador deficiente tarefas inadequadas; 
i) designar para o exercício de funções triviais o empregado de funções técnicas, especializadas, ou aquelas para as quais, de qualquer forma, exijam treinamento e conhecimentos específicos;

j) transferir imotivadamente o empregado do ambiente de trabalho, turno, setor, sala ou localidade;

k) sugerir ou induzir pedido de demissão a subordinado ${ }^{I}$

l) manter o empregado em condições precárias de segurança e saúde para o exercício profissional;

m) manter o empregado em estado de ociosidade, sem prévia motivação;

n) Designar o empregado para exercer função incompatível com o cargo;o) Utilizar, de forma maliciosa, informações sobre estado de saúde física ou mental do empragado; (BRASIL, 2009)

Essa redação, abrange tudo o que poderia configurar o assédio moral, não bastando isso, o $\S 1^{\circ}$, do art. $4^{\circ}$, ampliou a ocorrência do assédio moral para fora da jornada de trabalho, desde que haja nexo causalidade.

Outro fator importante, do Projeto de Lei n. 6.625 de 2009, é a observância do princípio da prevenção, ${ }^{2}$ ao estabelecer que é dever do empregador realizar campanhas educativas junto a funcionário, visando à melhoria das relações de trabalho. (BRASIL, 2009)

Além disso, o Art. $7^{\circ}$ prevê a criação de um código de interação com o propósito de combater a prática de assédio moral:

Art. $7^{\circ} \mathrm{O}$ órgão empregador deve elaborar um código de interação com o propósito de combater a prática de assédio moral, inclusive com a imposição de sanções disciplinadoras:

$\S 1^{\circ} \mathrm{Na}$ elaboração do código de interação, é assegurada a participação das entidades sindicais representantes dos trabalhadores.

$\S 2^{\circ} O$ código de interação deverá ser afixado nos locais públicos de circulação dos empregados e registrado junto ao Ministério do Trabalho ou às Delegacias Regionais do Trabalho da localidade ou da empresa ou órgão público.(BRASIL, 2009)

Ressalte-se, também, que o Projeto de Lei n. 6.625 de 2009 prevê ampla participação do sindicato dos trabalhadores que podem tanto ingressar em Juízo, como substitutos processuais, quanto participar na elaboração do código de interação.

${ }^{2}$ O princípio da prevenção, aplica-se quando verificada a necessidade de afastar o dano já que foi devidamente definido e demonstrado de maneira certa e determinada por experts, de sorte a evitar os resultados indesejáveis a meio ambiente em situações de risco, ou seja, informa a tomada de decisão previamentente ao advento do dano. ARRUDA, Carmem Silva Lima de Arruda. Princípios do direito ambiental. Revista CEJ, N. 62, Ano XVIII, Brasília, p. 96-107, jan/abr. 2014 Disponível em: http://www.jf.jus.br/ojs2/index.php/revcej/article/viewFile/1864/1817 Acesso em: 08 jul. 2015, p 101 O dano conhecido seria as descobertas das consequências do assédio moral pelos estudo da psicodinâmica do trabalho, de Dejours. O resultado indejável seria o meio ambiente de trabalho hostil, com empregados adoecendo psicoligicamente. 
Quanto a última tramitação do Projeto de Lei n. 6.625 de 2009, que até não foi submetido à aprovação, foi recebido pela Comissão de Trabalho, de Administração e Serviço Público.

\subsubsection{O assédio moral como improbidade administrativa: Projeto de Lei do Senado n. 121 de 2009.}

O terceiro, Projeto de Lei do Senado n. 121 de 2009, de autoria do Senador Inácio Arruda do PCdoB/CE far-se-ia incluir a tipificação constante no art. 117, inciso XX, ao rol de proibições previstas na Lei n. 8.112/90, com o fim de erigir a ilícito administrativo disciplinar o assédio moral, conforme a redação, que aqui trancreve-se:

Art. $1^{\circ}$ Acrescente-se o inciso XX ao art. 117 da Lei $n^{o}$ 8.112, de 11 de dezembro de 1990, com a seguinte redação:

Art.117......

$X X$ - coagir moralmente subordinado, através de atos ou expressões reiteradas que tenham por objetivo atingir a sua dignidade ou criar condições de trabalho humilhantes ou degradantes, abusando da autoridade conferida pela posição hierárquica."

Art. $2^{\circ}$ O inciso XIII do art. 132 da Lei $n^{\circ} 8.112$, de 11 de dezembro de 1990, passa a vigorar com a seguinte redação:

“Art.132.

$X I I I$ - transgressão dos incisos IX a XVI, e XX, do art. 117. (NR) (BRASIL, 2009)

Submetido à Comissão de Constituição, Justiça e Cidadania, o relator ad hoc Senador

Pedro Taques, no parecer n. 886, de 2014, analisou que houve um vício de inciativa decorrente de sua apresentação por parlamentar, em violação ao que dispõe o art. $61, \S 1^{\circ}$, II, $c$, da Constiuição Federal. Segundo Pedro Taques:

A iniciativa de projetos de lei referentes a servidores públicos e seu regime jurídico compete ao Chefe do Poder Executivo respectivo e nem mesmo a sanção pode convalidar o vício de iniciativa e sanar a inconstitucionalidade formal de proposições que violem esse preceito, como decidiu o Pretório Excelso na Ação Direta de Iinconstitucionalidade n. 2. 192, entre outras.(BRASIL, 2014) 
Para sanar o vício, o relator propôs manter a definição dada pelo autor do projeto em análise, mas com emenda substitutiva para que essa definição seja acrescentada como inciso VII, ao art. 11 da Lei n. 8.429, de 1992, criando assim, nova hipótese de improbidade administrativa que atente contra os princípios da Administração Pública.(BRASIL,2014)

Finalizando, Pedro Taques preceitua, que essa alternativa não apenas contorna a inconstitucionalidade formal da proposição original, como também estende o combate à odiosa prática do assédio moral a todos os entes da Federação. Ficando a redação do Projeto de Lei do Senado n. 121, de 2009, da seguinte forma:

EMENDA $N^{\circ} 1$ - CCJ (SUBSTITUTIVA)

PROJETO DE LEI DO SENADO N ${ }^{\circ} 121$, DE 2009

Altera a Lei $n^{\circ} 8.429$, de 2 de junho de 1992, para caracterizar o assédio moral como ato de improbidade administrativa.

O CONGRESSO NACIONAL decreta:

Art. $1^{\circ}$ O art.11 da Llei $n^{\circ}$ 8.429, de 2 de junho de 1992, passa a vigorar acrescido do seguinte inciso VIII:

Art.11..

VIII - "coagir moralmente subordinado, por meio de atos ou expressões reiteradas que tenham por objetivo atingir a sua dignidade ou criar condições de trabalho humilhantes ou degradantes, abusando da autoridade conferida pela posição hierárquica" (NR)

Art. $2^{\circ}$ Esta Lei entra em vigor na data de sua publicação.(BRASIL,

Na verdade, Pedro Taques fundamentou-se no REsp 1286466/RS, da segunda turma do Superior Tribunal de Justiça (STJ), sob a relatoria da Ministra Eliana Calmon, que impôs ao ex-Prefeito de Cangaçu, Odilon Mesko, multa equivalente a cinco anos de seu salário no cargo, além de três anos de suspensão de direitos políticos, por ter praticado assédio moral.

O entendimento do STJ, inédito, foi de que o assédio moral é ato contrário aos princípios da administração pública e sua prática se enquadra como improbidade administrativa.

Conforme a Ministra Eliana Calmon, que relatou o processo, que aqui colaciona-se, o assédio moral se configura por uma campanha de terror psicológico pela rejeição da vítima, indo além de provocações no local de trabalho como sacarmos, crítica, zombaria ou trote. A vítima é submetida à difamação, abuso verbal, agressões e tratamento frio e impessoal.

ADMINISTRATIVO. AÇÃO CIVIL PÚBLICA. IMPROBIDADE ADMINISTRATIVA. ASSÉDIO MORAL. VIOLAÇÃO DOS PRINCÍPIOS DA ADMINISTRAÇÃO PÚBLICA. ART. 11 DA LEI $8.429 / 1992$. ENQUADRAMENTO. CONDUTA QUE EXTRAPOLA MERA IRREGULARIDADE. ELEMENTO SUBJETIVO. DOLO GENÉRICO. 
1. O ilícito previsto no art. 11 da Lei 8.249/1992 dispensa a prova de dano, segundo a jurisprudência do STJ.

2. Não se enquadra como ofensa aos princípios da administração pública (art. 11 da LIA) a mera irregularidade, não revestida do elemento subjetivo convincente (dolo genérico).

3. O assédio moral, mais do que provocações no local de trabalho sarcasmo, crítica, zombaria e trote -, é campanha de terror psicológico pela rejeição.

4. A prática de assédio moral enquadra-se na conduta prevista no art. 11, caput, da Lei de Improbidade Administrativa, em razão do evidente abuso de poder, desvio de finalidade e malferimento à impessoalidade, ao agir deliberadamente em prejuízo de alguém.

5. A Lei 8.429/1992 objetiva coibir, punir elou afastar da atividade pública os agentes que demonstrem caráter incompatível com a natureza da atividade desenvolvida.

6. Esse tipo de ato, para configurar-se como ato de improbidade exige a demonstração do elemento subjetivo, a título de dolo lato sensu ou genérico, presente na hipótese.

\section{Recurso especial provido. ${ }^{3}$}

Para a Administração Pública, sem dúvida alguma, o Projeto de Lei do Senado 121 de 2009 seria um grande instrumento jurídico de combate ao Assédio Moral, embora, o mesmo, desde 02 (dois) de dezembro de 2014, ao ser remetido à Câmara dos Deputados, não tenha nenhum avanço.

Entretanto, essa não é a posição do Sandro Lucio Dezan, que tece duras críticas à redação do Projeto de Lei do Senado Federal n. 121/2009:

Todavia, apesar do louvável esforço e do reconhecido avanço éticomoral, o legislador ordinário ainda deixaria escapar uma singular oportunidade de também tipificar, no mesmo texto legal, o assédio do subordinado para com o chefe, a coação moral invertida ou ascendente na relação hierárquica, ou seja, aquela também comumente corriqueira nos meandros das repartições públicas e caracterizada pela situação em que o agente público subordinado, muitas vezes detentor de prestígio junto aos demais servidores ou possuidor de conhecimentos técnicos exclusivos ou específicos e de interesse para o bom andamento do serviço, põe-se em oposição aos nobres, legais e necessários propósitos administrativos de seu chefe imediato e direto, ou indireto, prejudicando os resultados sob o encargo do administrador e, de todo modo, coagindo, humilhando, degradando psicologicamente o agente público detentor de posição de hierarquia superior nos quadros da Administração. (DEZAN, 2013)

${ }^{3}$ BRASIL, Superior Tribunal de Justiça. Recurso Especial n. 1.286.466. Recorrente: Ministério Público do Estado do Rio Grande do Sul. Recorrido: Odilon Almeida Mesko. Relatora: Ministra Eliana Calmon. Rio Grande do Sul, 03 de setembro de 2013. Diponível em: https://ww2.stj.jus.br/processo/revista/documento/mediado/?componente=ATC\&sequencial=30526819\&num_re gistro=201100585605\&data=20130918\&tipo=5\&formato=PDF Acesso em: 15 jul. 2015. 
Dezan não deixa de ter razão, acrescenta-se, ainda, o assédio moral que pode ser classificado, na linha horizontal, ou simétrica, no momento em que o assédio é desenvolvido entre os colegas, não estando previsto o referido projeto de lei.

Se o Projeto de Lei do Senado n. 121/2009 for aprovado, uma dúvida, ainda, poderia perdurar, e o setor trabalhista privado ficaria desamparado legalmente?

\subsubsection{Assédio moral, uma ofensa moral equiparada ao acidente de trabalho: Projeto de Lei n. 7.202 de 2010 .}

O quarto Projeto de Lei n. 7.202 de 2010, elaborado por: Ricardo Berzoini, Pepe Vargas, Jô Moraes, Paulo Pereira da Silva e Roberto Santiago é muito interessante para esta pesquisa.

Referido projeto de lei protege o setor privado contra o assédio moral, pois objetiva equiparar ao acidente do trabalho a ofensa moral, conforme abaixo o transcreve:

Projeto de Lei 7.202, de 2010.

Altera a alínea " $b$ " do inciso II do art. 21 da Lei no 8.213, de 24 de julho de 1991, para dispor sobre situação equiparada ao acidente de trabalho ao segurado do Regime Geral de Previdência Social.

$O$ Congresso Nacional decreta:

"Art. $1^{\circ} \mathrm{O}$ art. 21 da Lei $n^{\circ} 8.213$, de 24 de julho de 1991, passa a vigorar com a seguinte redção:

Art.21.

II.

b) ofensa física ou moral intencional, inclusive de terceiro; ." (NR)

Art. $2^{o}$ Esta lei entra em vigor na data de sua publicação.(BRASIL,2010)

Como o assédio moral poderia ser equiparado ao acidente de trabalho? Rosemari Pedrott de Avila (2015, p.67) explana que o Decreto $\mathrm{n}^{\circ} 3.048$, de 06 de maio de 1999 (Regulamento da Previdência Social), em seu Anexo II, Lista B, elenca os transtornos mentais e do comportamento relacionado com o trabalho como agentes patogênicos causadores de doenças profissionais ou do trabalho. Dentre esses agentes patogênicos, são enumeradas doenças como:

[...] reações ao stress grave e transtornos de adaptação (identificado pela CID -10 sob F43._; Estado de Stress Pós Traumático (CID10 F43.1); transtornos mentais e comportamentais devidos ao uso do álcool: alcoolismo crônico (relacionado com o trabalho) (CID-10 F10.2), outros 
transtornos neuróticos especificados (inclui Neurose Profissional) (CID-10 F48.8); transtornos do ciclo vigília-sono devido a fatores não orgânicos (CID-10 F51.2); sensação de estar acabado (Síndrome de Burn-out, Síndrome do Esgotamento Profissional") (CID10 Z73.0)

$\mathrm{O}$ assédio moral não é uma brincadeira de mal gosto, é uma violência perversa que, conforme Marie-France Hirigoyen, produz consequências, mesmo quando o mesmo é recente, ou, se prolonga por mais tempo.

Segundo Hirigoyen (2010, p. 159):

Quando o assédio moral é recente e existe ainda uma possibilidade de reação ou uma esperança de solução, os sintomas são, no início, parecidos com os do estresse, o que os médicos classificam de perturbações funcionais: cansaço, nervosismo, distúrbios do sono, enxaquecas, distúrbios digestivos, dores na coluna.

No entanto, se o assédio moral se prolonga por mais tempo a vítima poderá sofrer depressão, que começa, de acordo com Hirigoyen (2010, p.159), com a apatia, tristeza, complexo de culpa, obsessão e até desinteresse por seus próprios valores.(HIRIGOYEN, 2010, p.159). Conforme Hirigoyen:

- 69\% das respostas acusaram um estado depressivo severo que justificou acompanhamento médico, por significar sério risco de suicídio. Estes números têm, aliás, correlação com a solicitação de ajuda das pessoas que, segundo nosso levantamento, consultaram seus médicos em $65 \%$ dos casos e um psiquiatra em $52 \%$ deles;

- $7 \%$ das pessoas apresentaram um estado depressivo moderado;

- $24 \%$ um estado depressivo leve. ${ }^{4}$

Além da depressão o assédio moral prolongado pode provocar distúrbios psicossomáticos, segundo Hirigoyen (2010, p. 161), após um certo tempo de evolução dos procedimentos de assédio, os distúrbios psicossomáticos passam quase sempre ao primeiro plano.

A vítima tenta aguentar as agressões ao máximo, mas o corpo, logo, emite seus sinais de alerta, após esse trauma, através dos distúrbios psicossomáticos, que segundo Hirigoyen(2010, p. 160) acontecem sob a forma de:

[...] emagrecimento intensos ou então rápidos aumentos de peso (quinze a vinte quilos em alguns meses), distúrbios digestivos (gastrite, colites, úlceras de estômago), distúrbios endocrinológicos (problemas de tireóide, menstruais), crises de hipertensão arterial incontroláveis, mesmo sob tratamento, indisposições, vertigens, doenças de pele etc. 
Não há dúvidas de que o assédio moral pode provocar, por exemplo, Estado de Stress Pós Traumático (CID-10 F43.1), por que não equipará-lo como um acidente de trabalho?

Seria uma forma do Estado ter acesso ao meio ambiente de trabalho que desequilibra o empregado mentalmente, já que o próprio Estado arcaria com esse empregado que teve uma diminuição, ou perda total, das possibilidades em obter os mesmos rendimentos por meio da força de trabalho que o empregado dispunha antes do fato ocorrido.

Conforme a redação do art. 22, da Lei 8.213, de 24 de julho de 1991, em caso de acidente do trabalho a própria previdência social deverá ser comunicada, veja-se:

Art. 22. A empresa ou o empregador deverão comunicar o acidente do trabalho à Previdência Social até o primeiro dia útil seguinte ao da ocorrência e, em caso de morte, de imediato, à autoridade competente, sob pena de multa variável entre o limite mínimo e o limite máximo do salário de contribuição, sucessivamente aumentada nas reincidências, aplicada e cobrada pela Previdência Social.

$[\ldots]$

$\$ 2^{\circ} \mathrm{Na}$ falta de comunicação por parte da empresa, podem formalizá-lo o próprio acidentado, seus dependentes, a entidade sindical competente, o médico que o assitiu ou qualquer autoridade pública, não prevalecendo nestes casos o prazo previsto neste artigo.(BRASIL, 1991)

A ofensa moral, isto é, assédio moral no setor privado existe, e na verdade, segundo Hirigoyen (2010, p. 145), é nelas que mais se localizam os casos de assédio moral consciente e deliberado, com o objetivo de fazer o empregado perder o ânimo até que resolva pedir demissão.

Para ilustrar a ocorrência do assédio moral no setor privado, cita-se uma pesquisa realizada entre bancários de todos o país a qual mostrou que,

[...] entre as reinvindicações relativas à saúde, condições de trabalho e segurança, $65 \%$ da categoria apontaram como prioridade a necessidade de combate ao assédio moral nos locais de trabalho. Cerca de $57 \%$ dos bancários pesquisados também querem o fim das metas abusivas. ${ }^{5}$

Este modelo de gestão programado para gerar lucros, chama-se de assédio moral organizacional, cujo custo é a saúde mental do trabalhador. Os estudos sobre psicologia são usados para gerar mais lucros aos empregadores.

Foi o aumento deste modelo de gestão agressor que motivou os autores do Projeto de Lei n. 7.202 de 2010, cuja justificativa assim dispõe

O objetivo do Projeto de Lei apresentado é estender o conceito de outras situações equiparadas ao acidente de trabalho. A ofensa moral cada

5 O estudo foi divulgado em 2013, durante a Conferência Nacional dos Trabalhadores do Ramo Financeiro. In:MELO, Anucha. Reduzido a cinzas. Revista do Ministério Público do Trabalho. Ano II. N. 5. 2014 Disponível em: $\quad$ http://portal.mpt.mp.br/wps/wcm/connect/portal_mpt/a9d2c6c4-425e-4beb-a6314826b7334573/Labor_n5.pdf?MOD=AJPERES\&CONVERT_TO=url\&CACHEID=a9d2c6c4-425e-4beb-a6314826b7334573 Acesso em: 27 jul. 2015 P. 20

Rev. de de Direitos Fundamentais Nas Relações Do Trabalho, Sociais E Empresariais | e-ISSN: 2525-9903 | Goiânia| v. 5 | n. 1 | p.58-81| Jan/Jun. 2019 
vez mais vem sendo reconhecida como fator de risco nos ambientes de trabalho, destacando-se o assédio moral e outras formas de violência.(BRASIL, 2010)

Atualmente, quem alega ser vítima do assédio moral tem que provar, por documentos, e, principalmente, por testemunhas, o que não é tarefa fácil, pois, os colegas de trabalho que podem testemunhar a violência psicológica, não o fazem por medo de ficar desempregados.

Se a ofensa moral, por motivo de disputa relacionada ao trabalho, for considerada doença profissional, a tão sonhada inversão do ônus da prova ocorrerá. Já que hoje os Tribunais Trabalhistas têm decidido pela necessidade de comprovação do assédio moral pelo assediado, conforme o acódão abaixo do Tribunal Regional do Trabalho da $23^{\mathrm{a}}$ Região.

ASSÉDIO MORAL. NÃO-CONFIGURAÇÃO. O terror psicológico dentro da empresa, que caracteriza o assédio moral, é manifestado através de comunicações verbais e não-verbais, como gestos, suspiros, levantar de ombros, insinuações, zombarias, que visam desestabilizar emocionalmente o empregado, humilhá-lo, constrangê-lo, colocando em risco a continuidade da relação laboral. A prova hábil a configurar o assédio moral, por sua vez, deve ser robusta, com precisa descrição do método empregado pelo infrator, a fim de possibilitar identificar seus elementos e suas características particulares. No caso, no entanto, a reclamante não conseguiu desincumbir-se do ônus de provar que sofreu humilhações por parte da empregadora, fato constitutivo de seu direito, de molde que não há de falar em indenização por danos morais.

(TRT da 23. ${ }^{a}$ Região; Processo: 0000560-46.2014.5.23.0046 RO; Data de Publicação: 20/07/2015; Órgão Julgador: $1^{a}$ Turma-PJe; Relator: ROBERTO BENATAR

Com a a aprovação do Projeto de Lei 7.202 de 2010, a ofensa moral passaria constar em uma tabela de doenças que o INSS (Instituto Nacional de Seguridade Social) criou, segundo Antonio Alves (2015):

Por exemplo, um funcionário de um banco procura o INSS para pedir afastamento do trabalho por estresse emocional. O que o médico faz? Ele verifica o que é constante uma pessoa que trabalha no banco ter. Essa relação de doenças vai constar em uma tabela que o próprio INSS criou. Se estresse emocional aparecer na lista, o médico não quer nem saber se é por conta do banco ou não. Vai enquadrar como doença profissional. Cabe ao banco provar que o empregado não adquiriu a doença lá. O INSS ainda pode entrar com uma ação regressiva contra a empresa, cobrando que ela arque com os custos, com aquilo que ele gastou com o trabalhador

${ }^{6}$ MATO GROSSO. Tribunal Regional do Trabalho (23a Região). Recurso Ordinário n.000056046.2014.23.0046. Alta Floresta. Recorrente. Franciane de Paula Valentin. Recorrido. Pró-Clin - Soc. Mat. Assistência em Medicina Interna Ltda. Relator. Desembargador Roberto Benatar. Disponível em: http://portal.trt23.jus.br/ecmdemo/public/trt23 Acesso em: 28 jul. 2015 
Segundo Rosemari Pedrotti, devido às repercussões psicofísicas provocadas na vítima, o assédio moral deve ser encarado como uma doença profissional ou de infortúnio do trabalho. (AVILA, 2014, p. 69)

De acordo com Rosemari, como acima explanado, o assédio moral, no aspecto objetivo, levando em consideração o elemento organizacional: o contexto sóciolaboral, a equiparaç (2ão do assédio moral ao acidente de trabalho, por força do art. 20, I e II da Lei 8.213/91 ampliaria a proteção ao meio ambiente do trabalho, direito fundamental de todos os os trabalhadores.

Entretanto, não são todos que comungam da mesma opinião. Ivandick Rogrigues dos Santos Jr (2010). Afirma que:

[...] a proteção pretendida na alteração legislativa já existe no ordenamento jurídico previdenciário pela qual o projeto de lei proposto demonstra-se redundante, do ponto de vista da cobertura, e ambíguo, haja vista não definir com exatidão a hipótese de incidência da norma, fato capaz de acirrar ainda mais a tensa relação capital x trabalho.

Essa proteção que Ivandick Rofrigues afirma, seria o auxílio doença acidentário, correspondente a $91 \%$ do salário-de-benefício, pelo período em que durar a incapacidade para o trabalho, mesmo que decorrente de sequela física/psicológica decorrente de violência moral.

Até hoje, no ordenamento jurídico de âmbito federal não há nenhuma lei que disponha o assédio moral, há uma omissão legislativa sobre o assunto, o que dificulta a repressão e prevenção. O meio ambiente do trabalho fica, desta forma sem proteção e vulnerável a esse tipo de violência. A aprovação do Projeto de Lei 7.202/2010 poderia ser uma solução.

\subsubsection{Punição do empregador por omissão ao combate de assédio moral: projeto de Lei n. 3.760 de 2012.}

Por último, nem por isso menos importante, na verdade o mais atual, tem-se o Projeto de Lei n. 3.760 de 2012, elaborado pelo deputado federal do PCdoB da Bahia, Edson Pimenta.

O Projeto de Lei n. 3.769 de 2012 dispõe sobre o assédio moral nas relações de trabalho, da maneira mais completa do que todos os outros Projetos de Lei, acima expostos.

Num primeiro momento, considera-se a proteção contra o assédio moral disposta no Projeto de Lei n. 3.760 de 2012 a mais ampla, tendo em vista que a vedação do assédio moral será na relação de trabalho, e, não, na relação de emprego.

A ciência do direito enxerga distinção entre a relação de trabalho e a relação de emprego. Segundo Maurício Godinho Delgado (2012, p. 279): 
A primeira expressão tem caráter genérico: refere-se a todas as relações jurídicas caracterizadas por terem sua prestação essencial centrada em uma obrigação de fazer consubstanciada em labor humano. Refere-se, pois, a toda modalidade de contratação de trabaho humano modernamente admissível.

A proteção contra o assédio moral aconteceria nas relações de emprego, nas relações de trabalho autônomo, nas relações de trabalho eventual, e trabalho avulso e outras modalidades de pactuação de prestação de labor, inclusive, o trabalho de estágio.

A relação de emprego seria uma espécie do gênero, relação de trabalho, que, segundo Godinho Delgado, corresponde a um tipo legal próprio e específico, inconfundível com as demais modalidades de relação de trabalho ora vigorantes. Por isso não usa o termo relação de emprego.

Além da proteção prevista pelo Projeto de Lei n. 3.760 de 2012 ser mais ampla, por utilizar a expressão "relação de trabalho", o conceito dado para assédio moral pelo referido projeto, também, corresponde ao conceito adotado por esta pesquisa.

Entenda-se por assédio moral a reiterada e abusiva sujeição do empregado a condições de trabalho humilhantes ou degradantes, implicando violação da dignidade humana, por parte do empregador ou de seus prepostos, ou de grupo de empregados, bem como a omissão da legalidade e punição do assédio moral. (BRASIL, 2012)

Por este conceito, depreende-se todos os elementos constitutivos do conceito de assédio moral, acima discutidos, como: a) subjetivos, constituídos pelo sujeito ativo e passivo do assédio; b) elemento objetivo, integrado pela conduta típica; c) elemento teleológico, representado pela intencionalidade do agente agressor; e, d) elemento organizacional, que diz respeito ao contexto sócio laboral.

O primeiro elemento, o subjetivo, constituídos pelo sujeito ativo, no Projeto de Lei n. 3.760 de 2012, seria o empregador ou um de seus prepostos, ou de grupo de empregados, ou seja, abarcam tanto o assédio moral vertical cometido por superior hierárquico, ou, empregador, como o assédio moral horizontal, assim definido pelo projeto de Lei n. 3760 de 2012:

Art. $3^{\circ}$

[...]

$\S 2^{\circ}$ Praticam assédio moral horizontal dois ou mais empregados, quando debocham, ridicularizam, caluiam, difamam, injriam, sonegam informações ou dificultam, por qualquer meio, o pleno desempenho das atividades laborais de outro empregado. (BRASIL,2012) 
Num pequeno deslinde o Projeto de Lei n. 3.760 de 2012 não trata do assédio moral praticado pelo subordinado contra o superior hierárquico, geralmente, o que assumiu a chefia recentemente, visando o seu cargo, por exemplo.

O sujeito passivo, no Projeto de Lei n. 3.670 de 2012, seria um empregado, frisa-se, mais uma vez, que o mesmo não coloca o superior hierárquico, como sujeito ativo, o que seria um equívoco.

O segundo elemento constitutivo, o elemento objetivo, caracteriza-se pela conduta típica, que o Projeto de Lei n. 3.760 de 2012 tipifica, num rol exemplificativo como:

I - a exposição do empregado a situação constrangedora, praticada de modo repetitivo ou prolongado;

II - a tortura psicológica, o desprezo e a sonegação de informações que sejam necessárias ao bom desempenho das funções do empregado ou úteis ao desempenho do trabalho;

III - a exposição do empregado, em prejuízo de seu desenvolvimento pessoal e profissional, a críticas reiteradas e infundadas, que atinjam a sua saúde física, mental, à sua honra e à sua dignidade, bem como de seus familiares;

IV - a apropriação do crédito do trabalho do empregado; com desrespeito à respectiva autoria;

$V$ - a determinaçõ de atribuições estranhas ou atividades incompatíveis com o contrato de trabalho ou em condições e prazos inexequíveis;

$V I$ - a obstacularização por qualquer meio, da evolução do empregado na respectiva carreira;

VII - a ocorrência das hipóteses previstas na alíneas " $a$ ", " $b$ ”, “ $d$ ”, " $e$ " e " $g$ ", do art. 483 da Consolidação das Leis do Trabalho, aprovada pelo Decreto-Lei n. 5. 452 de $1^{\circ}$ de maio de 1943.(BRASIL,2012)

As ocorrências acima referidas seriam:

Art. 483 - O empregado poderá considerar rescindido o contrato e pleitear a devida indenização quando:

a) forem exigidos serviços superiores às suas forças, defesos por lei, contrários aos bons costumes, ou alheios ao contrato;

b) for tratado pelo empregador ou por seus superiores hierárquicos com rigor excessivo;

[...]

d) não cumprir o empregador as obrigações do contrato;

e) praticar o empregador ou seus prepostos, contra ele ou pessoas de sua famíia, ato lesivo da honra e boa fama;

[...]

g) o empregador reduzir o seu trabalho, sendo este por peça ou tarefa, de forma a afetar sensivelmente a importância dos salários.(BRASIL, 1943) 
O Projeto de Lei n. 3.760 de 2012 trouxe todas as condutas possíveis que possam configurar o assédio moral, e, se uma outra conduta que não esteja no rol do art. $2^{\circ}$ for praticada pelos sujeitos, os aplicadores do direito poderão entender como assédio moral.

O terceiro elemento, o elemento teleológico, representado pela intencionalidade do agente agressor, se configura pela exigência do Art. $1^{\circ}, \S 1^{\circ}$ do Projeto de Lei n. 3.760 de 2012, da reiteração da sujeição do empregado a condições de trabalho humilhantes ou degradante.(BRASIL, 2012)

E, o $\S 2^{\circ}$, do art. $1^{\circ}$, do Projeto de Lei n. 3.760 de 2012, deixa bem claro que o $o$ exercício do poder hierárquico e disciplinar do empregador e de seus prepostos nos limites da legalidade e do contrato de trabalho, não configura o assédio moral.

O sujeito ativo tem que ter a intenção de degradar a saúde mental do trabalhador ou transformar o meio ambiente do trabalho um meio ambiente hostil.

O último elemento seria o elemento organizacional, que diz respeito ao contexto sócio laboral, ou seja a sujeição do empregado a situações degradantes devem ocorrer no meio ambiente do trabalho.

Pode acontecer também que o meio ambiente de trabalho hostilizado pelo assédio moral seja um instrumento para sugar mais trabalho do empregado, que poderia trabalhar mais, se estivesse estressado.

Neste casos, entende-se que o empregador será responsabilizado, conforme o art. $3^{\circ}, \S$ $1^{\circ}$, do Projeto de Lei n. 3.760 de 2012 objetivamente, no caso de assédio moral presente no seu ambiente de trabalho, mesmo que seja praticado por um superior hierárquico, caso em que se tornará solidário.

Isso pode ser explicado pelo Princípio da Prevenção, princípio do Direito Ambiental, que se aplica no meio ambiente de trabalho, que o Projeto de Lei n. 3.760 de 2012 assim o dispõe:

$\S 3^{\circ} \mathrm{O}$ empregador e seus prepostos têm o dever de tomar medidas para prevenir a ocorrência de assédio moral, bem como, ciente da sua ocorrência, de promover imediatamente a devida apuração e punição do infrator. (BRASIL, 2012)

Até, porque se métodos preventivos forem adotados, inclusive a punição do sujeito ativo, previsto no art. $4^{\circ}$, do Projeto de Lei n. 3.760 de 2012, o juiz poderá atenuar a indenização do dano moral, que o assédio moral poderá configurar. 
$\$ 3^{\circ} \mathrm{O}$ assédio moral configura hipótese de dano moral nas relações de trabalho ensejando a respectiva indenização. O juiz devera considerar, para a fixação do valor indenizatório, entre outros fatores:

I- a posição social da vítima;

II - a situação econômica do ofensor;

III- a culpa do ofensor na ocorrência do eveno, quando superior hierárquico;

IV - as iniciativas preventivas e reprensivas do empregador e de seus prepostos no sentido de minimizar os efeitos da ocorrência do assédio moral;

$V$ - a avaliação médica e psicológica para verificar o dano e o nexo causal relacionado ao meio ambiente do trabalho.(BRASIL, 2012)

O assédio moral prejudica não apenas o empregador, mas também a empresa. Para Camila Pereira Pinto:

[...] evidencia a existência de riscos de sua ocorrência para a empresa, visto que tal prática provoca a deterioração do meio ambiente de trabalho e, consequentemente, uma diminuição importante do rendimento da equipe de empregados, ocasionando perdas para o empregador.(PINTO, 2012)

Se configurado o assédio moral o empregador poderá punir o sujeito ativo, independentemente da responsabilidade trabalhista, civil e penal, com as seguintes penalidades:

$$
\begin{aligned}
& \text { Art. } 4^{o}[\ldots] \\
& \text { I-advertência; } \\
& \text { II - suspensão; } \\
& \text { III-dispensa por justa causa; } \\
& \text { IV-multa.(PINTO, 2012) }
\end{aligned}
$$

No caso do assédio moral horizontal, se o superior hierárquico nada fizer em relação à prática do assédio moral horizontal por parte de grupo de empregados que lhes são subordinados direta ou indiretamente, incorrerá em justa causa, redação do $\S 5^{\circ}$, do art. $5^{\circ}$ do Projeto de Lei n. 3.760 de 2012.

Segundo Camila Pereira Pinto, o Projeto de Lei n. 3.760 de 2012 considera também como assédio moral a omissão na prevenção ou na punição destes abusos, não somente a prática comissiva.

O Projeto de Lei n. 3.760 de 2012 é o que trata do assédio moral de forma completa e pune, inclusive, a omissão do empregador, ao mesmo tempo em que, se métodos preventivos forem adotados, isso o beneficiaria.

Mas para que isso tenha eficácia o referido projeto deverá ser aprovado, o que ainda não aconteceu. $\mathrm{O}$ último andamento, deste projeto, foi o seu recebimento pela Comissão de Trabalho, de Administração e Serviço Público (CTASP), e, posterior publicação pela $\begin{array}{lllll}\text { Coordenção de Comissões } & \text { Permanentes }\end{array}$ 


\section{O ASSÉDIO MORAL COMO ILÍCITO PENAL: PROJETO DE LEI N. 4. 742 DE 2001.}

Em 12 de março de 2019, a Câmara dos Deputados volta sua atenção para esse relevante tema, o que fundamentou a própria elaboração deste trabalho.

O Projeto de Lei n. 4742 de 2001, do Deputado Federal de Pernambuco, Marcos de Jesus, dispõe sobre a criminalização do assédio moral no trabalho por meio da introdução do artigo 146-A, no Código Penal Brasileiro - Decreto-lei n. 2848, de 7 de dezembro de 1940com a seguinte redação:

Art. 146-A Desqualificar, reiteradamente, por meio de palavras, gestos ou atitudes, a autoestima, a segurança ou a imagem do servidor público ou empregado em vínculo hierárquico funcional ou laboral.

Pena: Detenção de 3 (três) meses a um ano e multa.(BRASIL, 2001)

$\mathrm{O}$ referido projeto passou por correções e reformas sendo que a versão final foi a seguinte:

Acrescenta o art. 136-A ao Decreto-Lei n. 2848, de 7 de dezembro de 1940, Código Penal Brasileiro, instituindo o crime de assédio moral no trabalho.

O Congresso Nacional decreta:

Artigo $1^{\circ}$ O Decreto-Lei n. 2.848, de 7 de dezembro de 1940, Código Penal Brasileiro, fica acrescido do art. 136-A, com a seguinte redação:

Art. 136-A Depreciar, de qualquer forma e reiteradamente a imagem ou o desempenho do servidor público ou empregado, em razão de subordinação hierárquica funcional ou laboral, sem justa causa, ou tratá-lo com rigor excessivo, colocando em risco ou afetando sua saúde física ou psíquica.

Pena - detenção de um a dois anos.

Artigo $2^{\circ}$ Esta lei entra em vigor na data de sua publicação.

Ressalte-se a utilização da expressão reiteradamente, que segundo Beltrami Sanches, foi sabiamente trazida ao texto. Ela demarca que a ocorrência do dano pode levar certo tempo. E que se trata de um crime onde a vítima é constantemente lesada. (BELTRAMI, 2007, p. 78)

A aprovação deste projeto significaria um grande avanço, pois o tipo penal corresponde ao conceito de assédio moral, acima discutido, que é a sujeição do empregado a situações humilhantes e vexatórias, reiteradas e prolongadas no tempo, produzidas por um superior hierárquico, um colega de trabalho ou até mesmo um subordinado, visando a sua humilhação e desestabilização emocional. O projeto vai além, ao abordar tanto o empregado, quanto o servidor público. 
Renato de Almeida Oliveira Muçouçah (2012, p.131) não concorda. Seu entendimento é que:

A criminalização do assédio moral, em que pese elevar o instituto à majestade da tutela penal é, a nosso ver, uma opção equivocada e retrógrada. No direito penal, a aplicação das penas tornaram-se um "inflação de dor sem sentido". Isso porque o sistema penal tipifica tantos os crimes, e em tantas e diferentes modalidades que se, todos fossem realmente punidos, talvez quase toda a sociedade estaria sufocada diante dele. O discurso penal não passa, portanto, de um instrumento de dominação social, de modo a inculcar medo e vigilância - uma vigilância socialmente panóptica, especialmente sobre setores mais vulnerárveis da sociedade.

Este trabalho não corrobora tal entendimento. A única proteção que o trabalhador vítima de assédio moral encontra, atualmente, no ordenamento jurídico seria uma rescisão indireta que segundo Gisele Mendes de Carvalho e Érika Mendes de Carvalho (2008, 2919) acarreta a necessidade deque seja ele quem abandone o seu posto de trabalho e, o que é pior, muitas vezes permite que o assediador ou assediadores fiquem completamente impunes.

\section{CONSIDERAÇÕES FINAIS}

O assédio moral, apesar de ser um fenômeno que sempre existiu nas relações humanas, é um assunto que, sobretudo nas relações de trabalho, somente na última década, ganhou destaque nas discussões doutrinárias. Diante de sua importância e relevância nas relações de trabalho, médicos, psicólogos, administradores, profissionais juslaborais e sindicatos, em nível mundial, começaram a voltar seus estudos para esse grave fenômeno, demonstrando a preocupação de diversas áreas do conhecimento, para com a efetiva tutela dos interesses das pessoas envolvidas nessa relação. No entanto, a discussão sobre o tema ainda é tímida, a despeito da existência do fenômeno em larga escala.

Conststou-se que assédio moral viola o direito fundamental ao meio ambiente de trabalho equilibrado, meio ambiente do trabalho que vem da clássica e pedagógica divisão do meio ambiente em quatro aspectos: meio ambiente natural, meio ambiente artificial, meio ambiente cultural e meio ambiente do trabalho.

O meio ambiente natural é constituído pelos recursos naturais, dentre eles a flora e a fauna. O meio ambiente artificial é tudo que o homem construiu, mesmo que seja para sua própria moradia, como, por exemplo, os edifícios urbanos, ou o que o homem construiu para o desfrute comunitário. 
Quanto ao meio ambiente cultural é tudo aquilo que represente as maneiras de o ser humano existir, pensar e se expressar, bem como os símbolos que revelem seus saberes, suas artes, cerimônias, tradições e os seus valores.

Por último, e o que mais interessou para essa pesquisa, tem-se o meio ambiente do trabalho como um conjunto de elementos que se relacionam com as condições do meio ambiente do trabalho e a organização do meio ambiente do trabalho.

Essa violência perversa que ameaça o meio ambientes de trabalho, como acima relatado, através de uma pesquisa às legislações, percebeu-se que não há nenhuma legislação federal que a proíba e puna, senão alguns projetos de lei relevantes, que, inclusive, a definem de maneira mais completa como no projeto de lei n. n. 3.760 de 2012, cujo conceito de assédio moral abrange todos os elementos constitutivos do conceito de assédio moral, conforme a classificação objetiva, que adotou-se nesta pesquisa.

Para finalizar, conclui-se que, para que haja um meio ambiente do trabalho equilibrado psiquicamente, uma regulamentação de âmbito federal deverá ser aprovada, para que o assédio moral seja devidamente punido e que um meio ambiente do trabalho passe ser, também, mentalmente equilibrado.

\section{REFERÊNCIAS BIBLIOGRÁFICAS.}

ALVES. Antonio. Assédio Moral como acidente de trabalho? Disponível em: http://www.administradores.com.br/artigos/carreira/assedio-moral-como-acidente-de-

trabalho/47288/ Acesso em: 28 jul. 2015

AVILA, Rosemari Pedrotti. Assédio moral no trabalho e sua equiparação a acidente de trabalho: breves notas sobre proposição do Projeto de Lei No 7.202/2010. Revista Global Manager. V. 14, N. 2, $2014 \quad$ Diponível em: http://ojs.fsg.br/index.php/global/article/viewFile/1254/1168 Acesso em: 21 jul. 2015. P. 67

BELTRAMI, Gisele Caversan. PALMA, Cláudio Sanches. O assédio moral como norma penal incriminadora. Intertemas Vol. 13, N. 13, 2007. Disponível em: http://intertemas.toledoprudente.edu.br/revista/index.php/Juridica/article/view/513/509

Acesso em: 06 jul 2015 p. 78 
BRASIL, Constituição da República Federativa do Brasil de 1988. Disponível em: http://www.planalto.gov.br/ccivil_03/constituicao/constituicaocompilado.htm Acesso em: 03 jul. 2015.

BRASIL. Decreto-Lei n. 5.452, de $1^{\circ}$ de maio de 1943. Aprova a Consolidação das Leis do Trabalho. Disponível em: http://www.planalto.gov.br/ccivil_03/decreto-lei/Del5452.htm Acesso em: 29 jul. 2015

BRASIL. Decreto n. 25.696, de 20 de outubro de 1948. Manda executar os Atos firmados em Montreal, a 09 de outubro de 1946, por ocasião da 29. ${ }^{a}$ Sessão da Conferência Geral da Organização Internacional do Trabalho. Disponível em: http://www2.camara.leg.br/legin/fed/decret/1940-1949/decreto-25696-20-outubro-1948454771-publicacaooriginal-1-pe.html Acesso em: 18 de abril de 2015.

BRASIL, Lei $\mathrm{n}^{\circ}$ 6.938, de 31 de agosto de 1981. Dispõe sobre a Política Nacional do Meio Ambiente, seus fins e mecanismos de formulação e aplicação, e dá outras providências. Disponíveis em: http://www.planalto.gov.br/ccivil_03/leis/L6938.htm Acesso em: 11 jun. 2015.

BRASIL. Lei no 8.213, de 24 de julho de 1991. Dispõe sobre os Planos de Benefícios da Previdência Social e dá outras providências. Disponível em: http://www.planalto.gov.br/CCIVIL_03/leis/L8213cons.htm Acesso em: 22 jul. 2015

BRASIL, Parecer n. 886 de 2014. Da comissão de constituição, justiça e cidadania, sobre o Projeto de Lei do Senado n. 121, de 2009, do Senador Inácio Arruda, que altera dispositivos da Lei n. 8.112, de 11 de novembro de 1990, que dispõe sobre o Regime Jurídico dos Servidores Públicos Civis da União, das Autarquisas e das Fundações Pública Federais. Disponível em: http://www.senado.gov.br/atividade/materia/getPDF.asp?t=156741\&tp=1 Acesso em: 09 jul. 2015

BRASIL, Projeto de Lei n. 4.742 de 2001. Introduz art. 146-A no Código Penal Brasileiro Decret0 Lei $n$. 2.648, de 7 de dezembro de 1940 - dispondo sobre o crime de assédio moral no trabalho. http://imagem.camara.gov.br/Imagem/d/pdf/DCD26MAI2001.pdf\#page=74 Acesso em: 06 jul 2015

BRASIL, Projeto de Lei n. 6.757 de 2010. Altera dispositivos da Consolidação das Leis do Trabalho (CLT), aprovada pelo Decreto-Lei n. 5. 452, de $1^{\circ}$ de maio de 1943, para dispor sobre coação moral. Disponível em: http://www.camara.gov.br/proposicoesWeb/prop_mostrarintegra?codteor=732630\&filename= PL+6757/2010 Acesso em: 08 jul 2015.

BRASIL, Projeto de Lei do Senado n. 121. Altera dispositivos da Lei $\mathrm{n}^{\circ}$ 8.112, de 11 de dezembro de 1990, que Dispõe sobre o Regime Jurídico dos Servidores Públicos Civis da União, das Autarquias e das Fundações Públicas Federais. Disponível em: http://www.senado.gov.br/atividade/materia/detalhes.asp?p_cod_mate=90254 Acesso em: 09 jul. 2015. 
BRASIL. Projeto de Lei n. 3.760 de 2012. Dispõe sobre o assédio moral nas relações de trabalho.

http://www.camara.gov.br/proposicoesWeb/prop_mostrarintegra?codteor=985980\&filename $=$ PL+3760/2012 Acesso em: 29 jul. 2015

CARVAlHO, Gisele Mendes de, CARVAlHO, Érika Mendes de $O$ assédio moral nas relações de trabalho: uma proposta de criminalização Disponível em: http://www.publicadireito.com.br/conpedi/manaus/arquivos/anais/brasilia/05 841.pdf Acesso em: 13 abril 2019

COMPARATO, Fábio Konder. Fundamentos dos Direitos Humanos. Instituto de Estudos Avançados da Universidade de São Paulo. Disponível em: http://200.144.182.46/publicacoes/textos/comparatodireitoshumanos.pdf Acesso em: 22 abril de 20015

DELGADO, Maurício Godinho. Curso de Direito do Trabalho. 11 ed. São Paulo: LTr, 2012. P. 279

DEZAN, Sandro Lucio. O Projeto de Lei do Senado Federal - PLS n. ${ }^{\circ} 121 / 2009$ e a tipificação do assédio moral no Serviço Público Federal. Disponível em: http://www.conteudojuridico.com.br/artigo,o-projeto-de-lei-do-senado-federal-pls-no-

1212009-e-a-tipificaca-odo-assedio-moral-no-servico-publico-federal,42873.html Acesso em: 15 jul. 2015

FARIAS, Talden Queiroz. Meio Ambiente do Trabalho. Revista Direito e Liberdade v. 6, n.2, p. 443-462. Jan/jun 2007 Disponível em: http://www.esmarn.tjrn.jus.br/revistas/index.php/revista_direito_e_liberdade/article/view/117/ 109Acesso em: 24 fev. 2015.

MUÇOUÇAH, Renato de Almeida. Assédio Moral Coletivo nas Relações de Trabalho. São Paulo: LTr, 2011. p.131

PINTO, Camila Pereira. Projeto de Lei n. 3.760/2012 - assédio moral nas relações de trabalho. Disponível em: http://projetoslegislativos.blogspot.com.br/2012/12/projeto-de-lei-n37602012-assedio-moral.html Acesso em: 29 jul. 2015.

SANTOS JUNIOR. Ivandick Rodrigues dos. Estudo legislativo referente ao projeto de lei $n$. 7.202/2010. Disponível em: http://s.conjur.com.br/dl/parecer-iasp-equiparacao-assedio.pdf Acesso em: 29 jul. 2015. 